\title{
ホットスタンピング工法による優れた形状凍結性発現機構
}

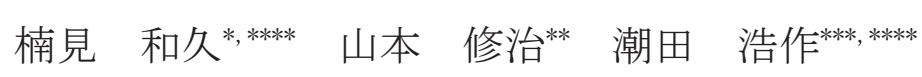

\section{Mechanism for Excellent Shape Fixability in Hot Stamping Process}

\author{
Kazuhisa KUSUMI ${ }^{* * * * *}$, Shuji YAMAMOTO** and Kohsaku USHIODA ${ }^{* * * * * * * *}$
}

(Received on June 11, 2018)

\begin{abstract}
Automobile body parts produced by the hot stamping process show excellent shape fixability with an ultra high tensile strength of $1.5 \mathrm{GPa}$. We investigated the effect of flow stress during forming and transformation after forming on shape fixability in the hot stamping process. Referring to the experimental and FEM coupled simulation results, we discussed the mechanism behind the excellent shape fixability in the hot stamping process. Steel of $0.2 \% \mathrm{C}$ was used for hot stamping in this study. IF steel and SUS 304, which have different transformation behaviors from that of $0.2 \%$ C steel, were used for comparison. The temperature of forming start was varied from 400 to $800{ }^{\circ} \mathrm{C}$. After hot stamping, the shape fixability of the parts was evaluated. The result showed that the excellent fixability in hot stamping was caused by not only low flow stress during stamping, but also martensitic transformation. When martensitic transformation occurs after stamping, excellent shape fixability is obtained without any relation to the flow stress during forming. Accordingly, it was concluded that the stress introduced by hot stamping is relaxed and becomes uniform throughout the thickness during martensitic transformation. In addition, the application of tensile stress due to thermal contraction also contributes to the decrease in spring back.
\end{abstract}

Key words: sheet metal forming, hot stamping, shape fixability, spring back, martensitic transformation, thermal contraction.

\section{1. 緒 言}

近年, 地球温暖化に対応した $\mathrm{CO}_{2}$ 排出量削減のために自 動車の燃費向上が必須となり, その軽量化が強く求められ ている.さらに衝突時の安全基準も厳しくなる方向であり, 車体部品に使用される鋼板の強度は著しく増加しており， 特性の優れた高強度鋼板が開発されている ${ }^{1)}$. 一方, 鋼板 強度の増加に伴ってプレス成形性は一般的に低下寸るため, 冷間プレスを用いた高強度部品の製造の難易度は上がって いる.

そこで, 高強度部品を製造するもう一つの方法としてホ ットスタンピング工法の適用が拡大している ${ }^{2)}$.この成形 方法では, 鋼板は $900^{\circ} \mathrm{C}$ 程度のオーステナイト域の温度に 加熱され，そののち常温の金型で成形され，金型で加圧中 に保持・冷却される結果, 焼きが入り高強度鋼板を得るこ とができる．この工法に用いられる鋼材の化学成分を調整 することにより，たとえば引張強度が $1.5 \mathrm{GPa}$ 程度で良好

* 新日鐵住金(株)八幡技術研究部 $\overline{7} 804-8501$ 北九州市戸畑区飛幡町 1-1 Nippon Steel \& Sumitomo Metal Corporation, Yawata laboratory,

1-1 Tobihata, Tobata, Kitakyushu, 804-8501, Japan.

*** 日鉄住金テクノロジー(株) †804-0001 北九州市戸畑区飛幡町 2-1 Nippon Steel \& Sumikin Technology,

2-1 Tobihata, Tobata, Kitakyushu, 804-0001, Japan.

****鉄住金総研(株) 广100-0005 東京都千代田区丸の内 3 丁目 1-1 Nippon Steel \& Sumikin Research Institute Corporation,

3-1-1 Marunouchi, Chiyoda, Tokyo, 100-0005, Japan.

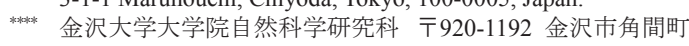
Kanazawa University, Graduate School of Science and Technology, Kakuma, Kanazawa, 920-1192, Japan.
な形状の部品が製造できる.

ホットスタンピング工法の大きな特徴は形状凍結性が顕 著に優れることにある. 一般的に鋼板の冷間プレス成形品 の形状精度は, 主に加工時に導入された残留応力が離型時 に解放される際にスプリングバック，壁そり，ねじれ等を 生じるため低下寸る ${ }^{3)}$. これらの形状変化の原因となる残 留応力は加工時に導入された応力の弾性回復が原因であり, 弾性回復量は加工時に生じた応力に比例する. そのため, 材料の強度が増加すると形状凍結性は悪化する ${ }^{4)}$. 一方, ホットスタンピング工法では成形が高温で行われるため材 料の変形抵抗が低く, 加工時の応力も低いために形状凍結 性が良好となると考えられる。実際には, ホットスタンピ ング工法により部品形状が金型形状とほぼ同じになるとい う結果 5)も得られており, 本工法における弾性回復は極め て小さい.しかし，成形温度がいかに高温であったとして も加工時には応力が導入されているので, それに起因する 弾性回復が生じて離型時に形状変化が生じることが予想さ れる。したがって, ホットスタンピング工法にて形状凍結 性が著しく良好となる理由には，高温で成形力が小さいこ と以外に別の因子があると考えられる。

応力以外の因子としては, ホットスタンピング中の金属 組織変化などの金属学的な影響があげられる ${ }^{6) ~ 8) . ホ ッ ト ~}$ スタンピング工法では成形後に材料が金型で急速冷却され ることによりマルテンサイト変態が生じ, その結果体積が 
増加し加工により導入された応力状態が変化する可能性が 考えられる. 通常のホットスタンピングに用いられる材料 よりも焼き入れ性が高い材料を用いた検討では，マルテン サイト変態時に材料を拘束することにより形状精度が向上 するという結果が示されている 6),7)。しかし，これらの結 果はクランクプレスを用いた通常のホットスタンピングと 異なる条件で行われたものである。一方では, 熱間成形で の形状凍結性に再結晶が関与するとの報告もされている ${ }^{8)}$ しかし, その研究ではフェライト単相域での加工が検討さ れており, 本研究が対象とするオーステナイトからのマル テンサイト変態を伴う通常のホットスタンピング技術とは 異なる工程での結果である.

本報告ではホットスタンピング工法に用いられる典型的 な鋼成分の材料を用いてハット曲げ成形を行い, まずホッ トスタンピングと冷間プレスとの比較を行った。その後, ホットスタンピング工法により形状凍結性が向上する効果 を，熱間変形抵抗の影響と成形後に生じるマルテンサイト 変態の影響の二つの観点から調査し, 良好な形状凍結性が 得られる機構について考察した. 熱間の変形抵抗は成形温 度を制御することにより変化させた。一方，マルテンサイ ト変態の影響は, 成形後にマルテンサイト変態が生じるホ ツトスタンピング用鋼板と変態が生じない比較鋼を用いて 調査した. また, 成形解析と冷却中の温度や変態挙動解析 とを連成させることにより，ホットスタンピング加工の形 状凍結性向上機構を考察した.

\section{2. 実験方法および数值解析方法}

\section{1 供試材}

板厚 $1.4 \mathrm{~mm}$, サイズ $241 \mathrm{~mm} \times 297 \mathrm{~mm}$ のホットスタンピ ング用アルミめっき鋼板を用いた 9), 10)。鋼成分は $0.22 \% \mathrm{C}-1.2 \% \mathrm{Mn}-0.002 \% \mathrm{~B}$ であり, 以下 $0.2 \% \mathrm{C}$ 鋼と称する. この鋼のマルテンサイト変態が生じる臨界冷却速度は $30^{\circ} \mathrm{C} / \mathrm{s}$ であり, マルテンサイト変態開始温度 $\mathrm{Ms}$ 点は $400^{\circ} \mathrm{C}$ 程度である ${ }^{10)}$. 成形後の金型冷却によりマルテンサイト変 態が生じる．形状凍結性に関する冷間プレスとの比較を目 的に, $270,440,590 \mathrm{MPa}$ 級冷延鋼板を用いた。比較材の引 張特性を Table 1 に示す。 また, 形状凍結機構を解明する ことを目的に，比較材として熱間成形後に変態が生じない $270 \mathrm{MPa}$ 級 IF（Interstitial Free）鋼（以下 IF 鋼）とオース テナイト系の SUS304 鋼を用いた.

Table 1 Tensile properties of specimens for cold stamping for comparison

\begin{tabular}{|c|c|c|c|}
\hline Class & YP $(\mathrm{MPa})$ & TS $(\mathrm{MPa})$ & El (\%) \\
\hline 270 & 152 & 305 & 49 \\
\hline 440 & 285 & 459 & 39 \\
\hline 590 & 410 & 640 & 34 \\
\hline
\end{tabular}

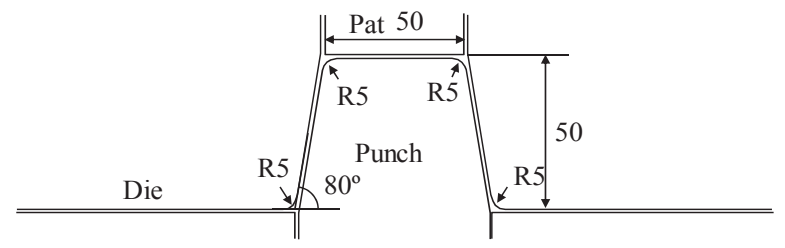

Fig. 1 Cross-sectional shape of the tool

\section{2 成形条件}

Fig. 1 に用いた工具の断面形状を示す.成形高さは $50 \mathrm{~mm}$, クリアランスは $1.4 \mathrm{~mm}$ であり, 部品長は $297 \mathrm{~mm}$ である. ホットスタンピング条件としては, 鋼板を $950{ }^{\circ} \mathrm{C} に$ 加熱し, 金型の上に搬送して油圧プレスにて成形した後，加圧力 $1500 \mathrm{kN}$ にて 10 秒間の下死点保持を行った. 比較の冷間プ レスは鋼板を常温のまま，ホットスタンピングと同じ条件 にて行った。

成形開始温度は, $950^{\circ} \mathrm{C}$ 加熱後の空冷途中の温度である $400 \sim 800^{\circ} \mathrm{C}$ 範囲で変化させた. Fig. 2 に $0.2 \%$ 鋼, IF 鋼, $\mathrm{SUS} 304$ 鋼の $950^{\circ} \mathrm{C}$ 加熱後の空冷途中における温度変化を 示寸. $0.2 \% \mathrm{C}$ 鋼は今回の空冷では $530^{\circ} \mathrm{C}$ 付近においてべイ ナイト変態による変態発熱が生じた。これより成形開始温 度 $550 \sim 800^{\circ} \mathrm{C}$ では $0.2 \% \mathrm{C}$ 鋼はオーステナイト相であり, 成 形後の金型冷却にてマルテンサイト変態すると考えられる. 一方，成形開始温度が $500^{\circ} \mathrm{C}$ 以下では加工前に主にベイナ イトを主体とする変態が完了していることを確認した．IF 鋼は $950^{\circ} \mathrm{C}$ 加熱時点ではオーステナイトであるものの, $850^{\circ} \mathrm{C}$ 付近でフェライト変態し,成形前にはフェライト変態 が完了している。また SUS304 鋼ではオーステナイト相が 安定で変態発熱は生じない. これより，550～800 ${ }^{\circ} \mathrm{C}$ の加工 温度範囲では IF 鋼とSUS304 鋼はそれぞれフェライトとオ ーステナイトであり, プレス成形後も変態は生じない.

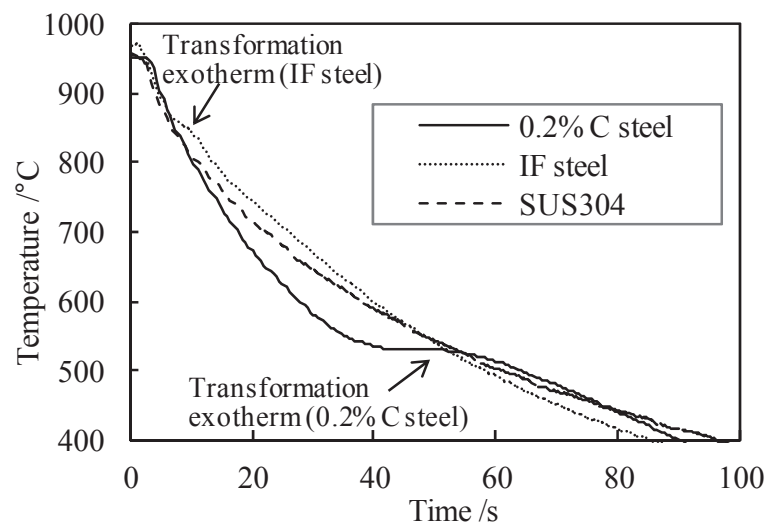

Fig. 2 Air-cooling curves for each type of steel

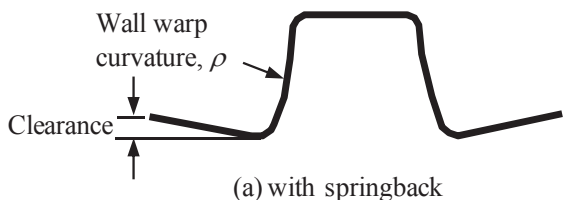

(a) with springback

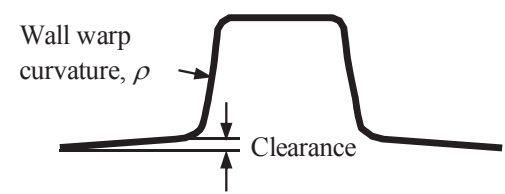

(b) with spring-go

Fig. 3 Evaluation method for shape fixability

\section{3 形状凍結性の評価}

形状凍結性は Fig. 3 に示すようにフランジ部と水平面と の隙間の測定と側壁中央部の壁そり（部品外側の曲率）を 測定した。隙間はスプリングバックしている場合はフラン ジ端部と水平面の隙間を測定し，スプリングゴーが生じた 
場合にはダイ肩 $\mathrm{R}$ 部の $\mathrm{R}$ 止まり部と水平面との隙間を測定

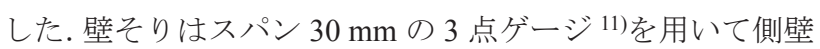
の中央部にて曲率を測定した。

\section{4 熱間引張強度}

熱間成形時の変形抵抗と形状凍結性との関係を考察する ために，熱間引張強度を測定した． IF 鋼と SUS304 鋼は， JIS G0567 に準拠し, 試験温度 $400,600,800^{\circ} \mathrm{C}$, ひずみ速度 $0.1 \mathrm{~s}^{-1}$ にて引張試験を行った.

$0.2 \% \mathrm{C}$ 鋼のベイナイト変態後の引張強度は, $0.2 \% \mathrm{C}$ 鋼を $950^{\circ} \mathrm{C}$ に加熱した後に室温まで空冷してべイナイト変態を 生じさせた材料を用いて JIS G0567 に準拠し, 試験温度 $400^{\circ} \mathrm{C}$, 歪速度 $0.1 \mathrm{~s}^{-1}$ の引張試験により求めた. また, $0.2 \% \mathrm{C}$ 鋼のオーステナイト域での引張強度は, 幅 $30 \mathrm{~mm}$ の短冊状 の試験片を用い, 富士電波工機の熱サイクル引張圧縮試験 装置で評価した。すなわち, $950^{\circ} \mathrm{C}$ 加熱した後に $30^{\circ} \mathrm{C} / \mathrm{s}$ で試験温度まで泠却し, 温度 $600,700,800^{\circ} \mathrm{C}$, 歪速度 $0.1 \mathrm{~s}^{-1}$ の引張試験を行った。

\section{5 数值解析方法}

本成形試験の FEM 解析は相変態の取り扱いが容易な DEFORM 3D ver. 11. 1.1 を用いて実施した. 解析モデルは, ブランクには弾塑性体ソリッド要素, ブランク近傍の金型 には弾性体ソリッド要素を用いた 3 次元モデルとした。高 温の加工硬化特性は, 円柱圧縮での実測結果に基づく温度, ひずみ速度依存性を考慮した志力一ひずみ曲線を用いるこ とにより評価した。 すなわち, 直径 $8 \mathrm{~mm}$, 長さ $12 \mathrm{~mm}$ の 円柱を $950^{\circ} \mathrm{C}$ に加熱した後に $50^{\circ} \mathrm{C} / \mathrm{s}$ で加工温度まで泠却し, ひずみ速度 $0.01,0.1,1 \mathrm{~s}^{-1}$ にて圧縮して, 応力ーひずみ曲線 を求めた．金型とブランクの熱伝達率は面圧に依存する值 を設定した ${ }^{12)}$. 摩擦係数は 0.55 とした ${ }^{13)}$. またマルテン サイト変態に伴う線膨張係数の変化は, 富士電波工機製フ オーマスター試験装置を用いてマルテンサイト変態が生じ る温度と熱澎張の関係を測定して求めた。 マルテンサイト 変態挙動は上記の実験から温度と変態率との関係を求めて,

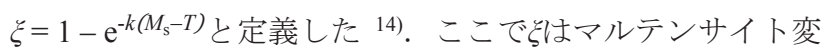
態率， $T$ は温度 $(\mathrm{K}), M_{\mathrm{S}}(\mathrm{K})$ と $k\left(\mathrm{~K}^{-1}\right)$ はそれぞれマルテンサ イト変態開始温度と定数であり, 実験結果から求めた。ま た, 変態中に応力が付加されると塑性変形が発生する変態 塑性という現象が生じる ${ }^{15)}$. 本検討では成形にて応力が導 入された後にマルテンサイト変態が生じるため, 変態塑性 が生じて応力状態に影響を及ぼす可能性が考えられる。そ のため, 変態塑性を考慮した. 変態率増分をd , 偏差応力 を $s_{i j}(\mathrm{MPa})$ とすると変態塑性ひずみ増分 $d \varepsilon_{i j}^{\mathrm{tp}}$ は, $d \varepsilon_{i j}^{\mathrm{tp}}=3 K(1-\xi) d \xi s_{i j}$ と表される ${ }^{15)}$. ここで $K\left(\mathrm{MPa}^{-1}\right)$ は変態 塑性係数と呼ばれ, 文献值 ${ }^{15)}$ を用いた. 冷却完了後にはブ ランクを金型から離してスプリングバックの解析も行った. また，比較として $590 \mathrm{MPa}$ 級冷延鋼板の冷間プレス成形時 のスプリングバックの解析も行った。

\section{3. 実験結果および考察}

\section{1 ホットスタンピングと冷間プレスの形状凍結性の 比較}

Fig. 4 に, 成形開始温度 $800^{\circ} \mathrm{C}$ のホットスタンピング材と 冷間プレス材の形状凍結性の比較結果（壁そり）を示す. 横軸の引張強度は, ホットスタンピング材ではホットスタ
ンピング後の強度, 冷間プレスでは素材の強度を示す。ま た Fig. 5 に成形品の外観を示寸。これらの図から明らかな ように, ホットスタンピングでは隙間, 壁そりとも発生し ておらず，極めて良好な形状凍結性を示した。一方，冷間 プレスでは材料の引張強度が増加するにしたがい，隙間と 壁そりの双方ともに増大した。成形後の形状をみると，側 壁のフランジに近い部位に壁そりが発生していた（Fig. 5). これはこの部位の成形が進むにつれ，ダイ肩 $\mathrm{R}$ 部で曲げら れた後に曲げ戻されて壁そりが生じためと考えられる.

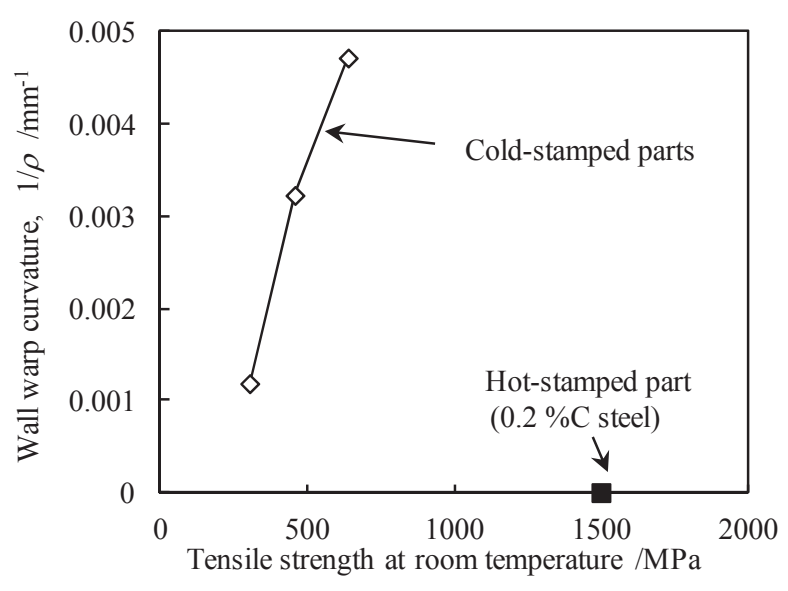

Fig. 4 Shape fixability of hot-stamped and cold-stamped parts

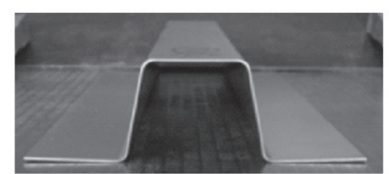

(a) Cold-stamped part

(270 MPa Class)

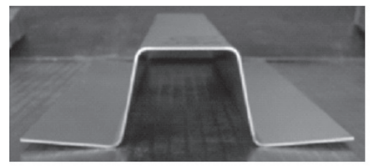

(b) Cold-stamped part (440 MPa Class)

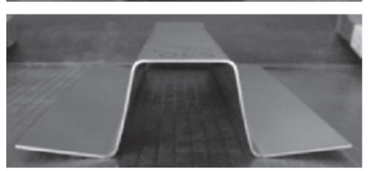

(c) Cold-stamped part (590 MPa Class)

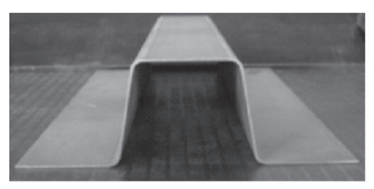

(d) hot-stamped part

$(0.2 \% \mathrm{C}$ steel $)$

Fig. 5 Appearance of stamped parts

\section{2 形状凍結性におよぼす成形開始温度と鋼種の影響}

Fig. 6 にホットスタンピング後の形状凍結性におよぼす 成形開始温度の影響を示す。

$0.2 \% \mathrm{C}$ 鋼では成形開始温度が $550 \sim 800^{\circ} \mathrm{C}$ の場合には隙間, 壁そりとも小さく, 良好な形状凍結性を示した。 しかし成 形開始温度が $500^{\circ} \mathrm{C}$ 以下の場合には形状が急激に悪化した. 成形開始温度が $550 \sim 800^{\circ} \mathrm{C}$ の場合はオーステナイト状態 から成形を開始しており, 成形後の下死点保持にてマルテ ンサイト変態が生じるのに対して, 成形開始温度が $500^{\circ} \mathrm{C}$ 以下ではベイナイト変態が生じた後に成形しており, 成形 後の下死点保持でマルテンサイト変態は生じていない。 上 記から成形後にマルテンサイト変態が生じた場合に形状凍 結性が良好となることが明らかとなった。 
これに対して, 成形後の下死点保持での冷却にてマルテ ンサイト変態が生じない IF 鋼と SUS304 鋼の場合では, 成 形開始温度が $800^{\circ} \mathrm{C}$ でもスフリングバックが存在し, 成形 温度が低下すると連続的に劣化した。これは加工温度の低 下とともに変形抵抗が増加して形状凍結性が劣化したもの と考えられる。これより，成形後にマルテンサイト変態が 生じない場合には高温で加工した場合でもスプリングバッ クが発生することが明らかとなった。

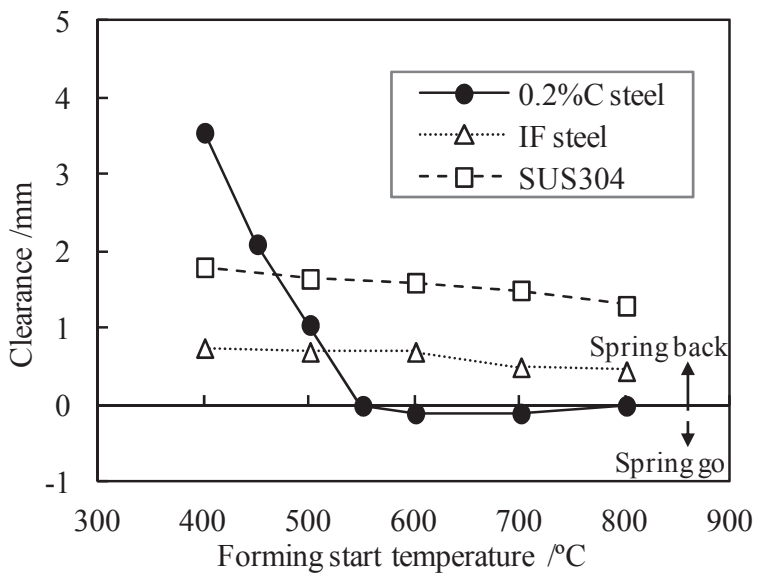

(a) Clearance

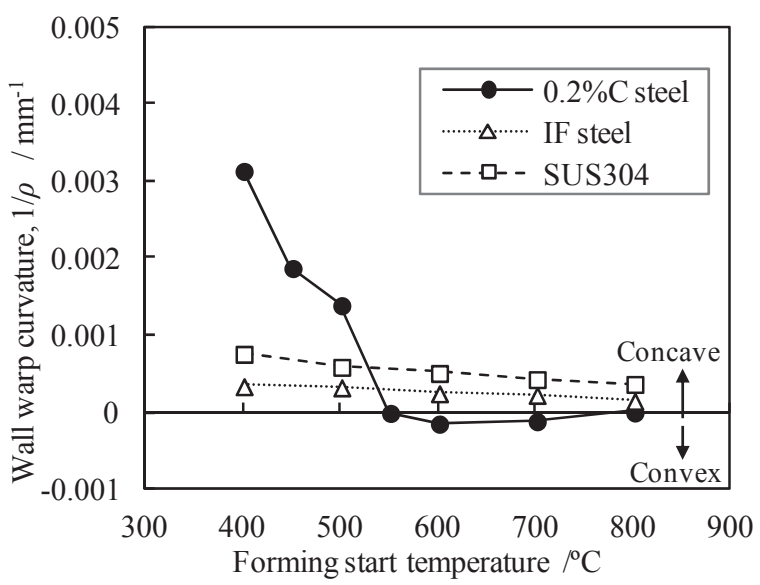

(b) Wall warp curvature

Fig. 6 Influence of forming start temperature on the shape fixability of hot-stamped part

\section{3 形状凍結性におよぼす熱間引張強度の影響}

Fig. 7 にホットスタンピング後の形状凍結性と熱間引張 強度との関係を示す。また，冷間プレスの結果も合わせて 示す。成形後にマルテンサイト変態が生じない IF 鋼, SUS304 鋼と $400^{\circ} \mathrm{C}$ で成形した $0.2 \% \mathrm{C}$ 鋼については, 形状 凍結性は熱間引張強度で整理でき, 成形時の強度が高いと 形状凍結性は低下した. 高温成形であっても加工力に応じ た弾性変形がスプリングバックを発生させたと考えられる。 また図から明らかなように，成形時の変形抵抗が同じであ っても，ホットスタンピングの方が冷間成形より形状凍結 性に優れる. ホットスタンピングでは, 3.5 にて後述する張 力付与の効果が寄与していると推察される.

一方， $0.2 \% \mathrm{C}$ 鋼を $600,700,800^{\circ} \mathrm{C}$ のオーステナイト域で 成形し，成形後にマルテンサイト変態させた場合には，形 状凍結性は熱間強度に関わらず, 顕著に小さい值を示した。

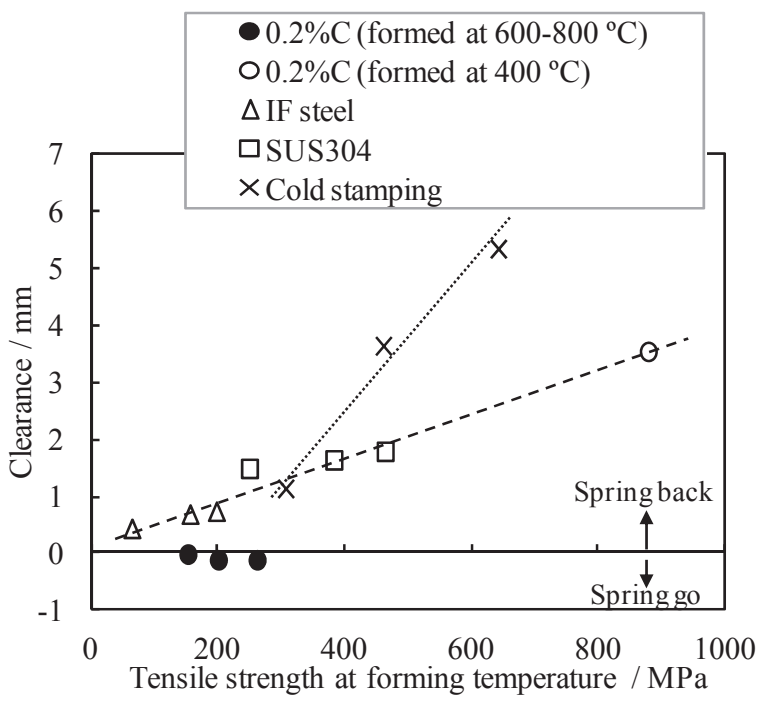

(a) Clearance

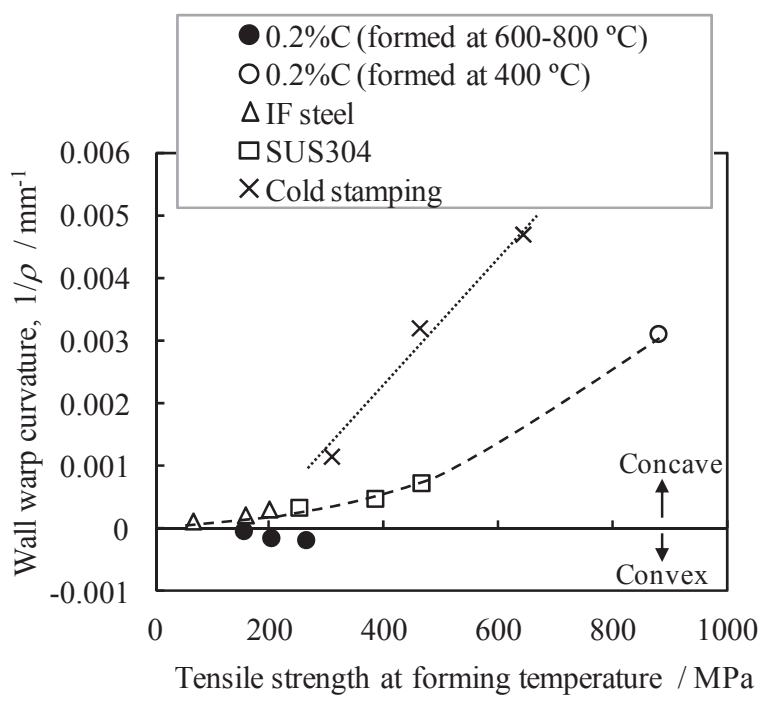

(b) Wall warp curvature

Fig. 7 Influence of the strength of the material at the forming temperature on the shape fixability of hot-stamped part

これより,成形後にマルテンサイト変態が生じる場合には, 熱間強度に関わらず良好な形状凍結性を示寸と考えられる.

3.4 数值解析による成形後, 冷却中の応力状態の変化

まず，比較として $590 \mathrm{MPa}$ 級冷延鋼板を用いた冷間プレ スにおける成形後の最大主応力分布と離型後の形状をそれ ぞれ Fig. 8, Fig. 9 に示す. パンチ肩 R 部では板の表裏での 応力差が大きく生じており，これが離型後に開く変形をも たらす原因となっている。また，側壁下部にも曲げ曲げ戻 しで導入された表裏の応力差が発生しており，離型後には 壁そりが発生している．解析でのフランジ端と水平面の隙 間は $4.5 \mathrm{~mm}$ であり，実成形の $5.35 \mathrm{~mm}$ とほぼ良い一致を 示した。

次に $0.2 \% \mathrm{C}$ 鋼を用いたホットスタンピング工法での解析 結果を示す. Fig. 10 は成形開始温度 $800^{\circ} \mathrm{C}$ の解析結果であ る. 成形完了直後（冷却開始）からの冷却途中における成 形品の温度分布とマルテンサイト相の体積分率の時間変化 を示す。冷却開始後 $0.07 \mathrm{~s}$ ではマルテンサイト変態が生じ ていない。冷却開始後 $0.47 \mathrm{~s}$ ではウェブ面と側壁の一部で マルテンサイト変態が生じた。冷却開始後 $0.87 \mathrm{~s}$ では側壁 


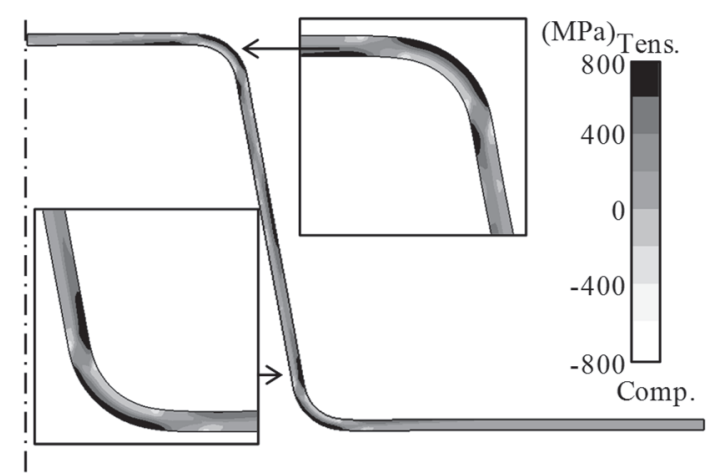

Fig. 8 Maximum principal stress distribution of the cold stamped part calculated by finite element simulation (590 MPa class)

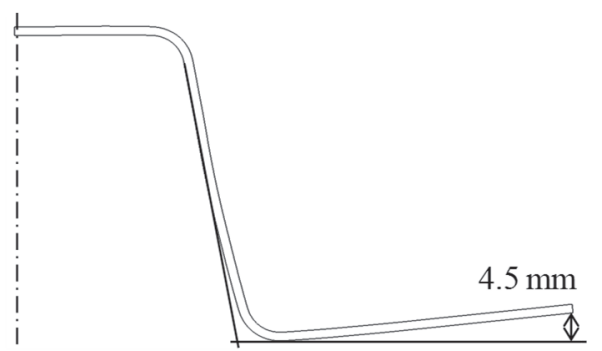

Fig. 9 Shape of the cold stamped part after unloading calculated by finite element simulation (590 MPa class)

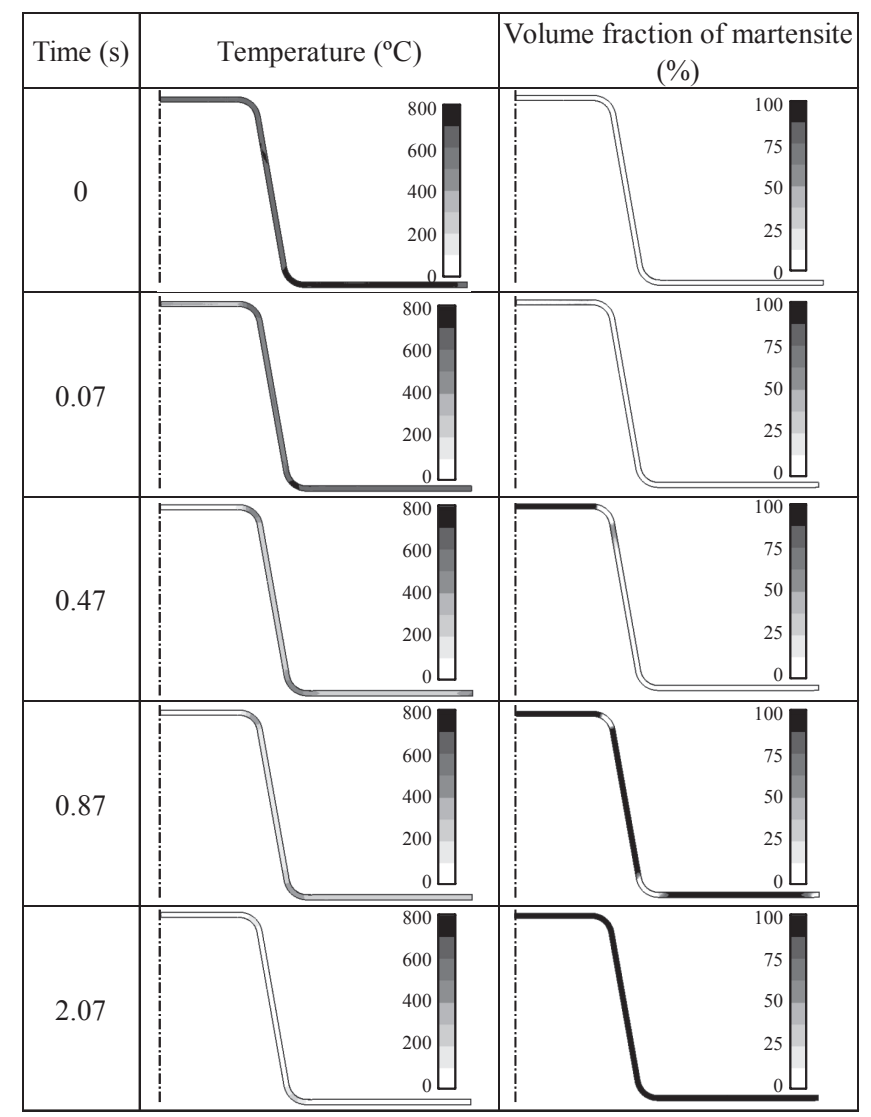

Fig. 10 Temperature distribution and change in volume fraction and distribution of martensite calculated by finite element simulation after forming and subsequent cooling in the hot-stamping process
のマルテンサイト変態は完了し, $2.07 \mathrm{~s}$ 後では部品全体で マルテンサイト変態が完了した。

Fig. 11 には最大主応力分布の時間変化を示す。ここでは パンチ肩 $\mathrm{R}$ 近傍，およびダイ肩 $\mathrm{R}$ 近傍と側壁下部の結果を 示した。 まず，成形直後では冷間プレスの結果と同様にプ レス成形により導入された応力が存在した。この時点にお いて，パンチ肩 $\mathrm{R}$ 部および側壁下部では板の表裏での応力 差が大きく生じており, 離型後にスプリングバックおよび 壁そりが生じる応力状態となっていた. 冷却開始後 $0.07 \mathrm{~s}$ において引張応力の発生が認められるが，これは温度低下 に伴う熱収縮によって生じたと考えられる. 冷却開始後 $0.47 \mathrm{~s}, 0.87 \mathrm{~s}$ では成形および熱収縮で導入された応力が減 少し，板厚表裏の応力もほぼ均一となった。これは，マル テンサイト変態に伴う膨張と変態塑性が影響したと考えら れる，すなわち，変態に伴う膨張により引張応力は減少し

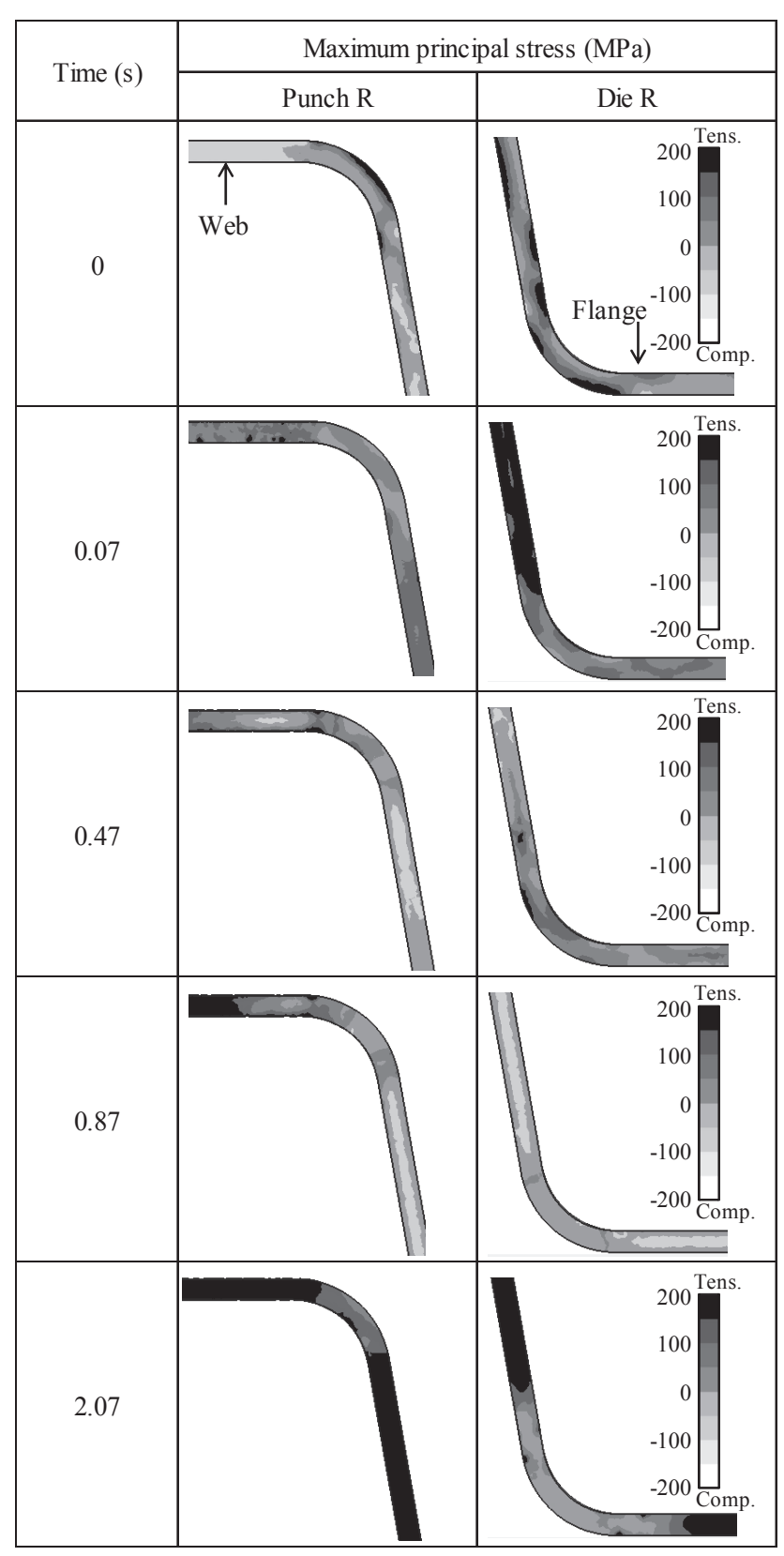

Fig. 11 Maximum principal stress distribution calculated by finite element simulation after forming and subsequent cooling in the hot-stamping process 


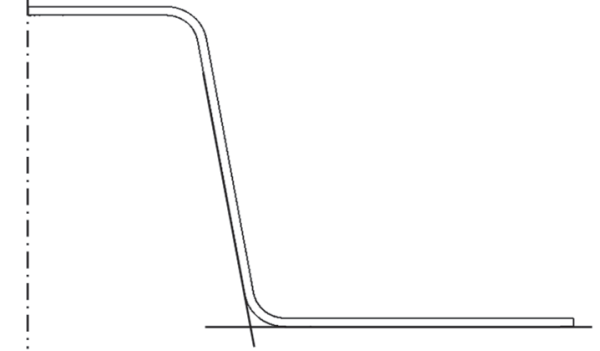

Fig. 12 Shape of the hot stamped part calculated by finite element simulation after unloading

たと考えられる。また変態塑性が生じると, 応力付加方向 にその值に応じた塑性変形が生じて板厚の表裏の応力差が 緩和したと推察される. $0.87 \mathrm{~s}$ 後のウェブ面では引張応力 が生じているが，これはこの部位ではマルテンサイト変態 が早く完了したため, その後の温度低下に伴う熱収縮によ るものと考えられる。冷却開始後 $2.07 \mathrm{~s}$ では再度引張応力 が発生した。これは，上記と同様に先にマルテンサイト変 態が完了した部位の熱収縮が原因であると考えられる。こ の時点で引張応力は生じているものの, 形状凍結不良の原 因となる表裏の応力差は存在しておらず, 離型により単純 に線長が縮むのみと考えた. Fig. 12 に離型後の部品形状を 示す.上記の応力状態を反映してスプリングバックや壁そ りは発生しておらず，マルテンサイト変態が生じた場合に は良好な形状凍結性を示すことが再現された。

\section{5 ホットスタンピングにおける形状凍結性発現機構}

上記の結果から, ホットスタンピングによる優れた形状 凍結性発現機構を考察する. 高温の成形であっても変形に 応じた応力が導入される.特にパンチ肩 $\mathrm{R}$ 部や側壁下部に は離型後の形状変化をもたらす応力が導入されやすい. 成 形が完了した後の泠却では熱収縮により引張応力が付与さ れる.これは, 冷間プレスでの張力付与 ${ }^{16)}$ の効果と同様に, スプリングバックや壁そりを低減する効果を有すると考え られる。 すなわち, 板の表裏に応力差が生じている応力状 態を, 引張曲げが引張側にそろえる効果を持つため, スプ リングバックや壁そりが小さくなると考えられる. 今回の 実験でもマルテンサイト変態が生じない IF 鋼や SUS304 鋼 において，ホットスタンピングでは，この効果が生じて冷 間プレスよりも形状が良好になったと推察した。さらに成 形後にマルテンサイト変態が生じる $0.2 \% \mathrm{C}$ 鋼では, 変態に よる膨張や変態塑性によって生じたひずみが成形により導 入された板厚方向の応力差を緩和するように作用したと考 えられる，この効果により，ホットスタンピングにて成形 後にマルテンサイト変態が生じる場合には, 形状凍結性が 顕著に良好となったと考えられる.

最後に, 成形シミュレーションは有用なツールであるこ とを確認したが，その多様な活用については今後の課題と したい.

\section{4. 結 言}

ホットスタンピング工法が顕著な形状凍結性向上効果を もつ機構を調査するため, 変態挙動の異なる比較材を用い てハット曲げ成形を行い, また温度や相変態と連成させた
FEM 解析を行った. 得られた知見は次のとおりである.

(1) ホットスタンピング工法による良好な形状凍結性は, 高温で成形力が小さいことだけでは説明できない。

(2) 形状凍結性は成形後にマルテンサイト変態が生じる場 合に著しく良好となる.

（3）マルテンサイト変態が生じた場合に形状凍結性が良好 となる理由は，変態に伴い残留応力が緩和して板表裏 面での応力差が低減するためと考えられる.

(4) 成形後にマルテンサイト変態が生じない場合には, 成 形時の強度に応じたスプリングバックが発生する。た だし，熱収縮により引張曲げの効果が生じるため，冷 間プレスよりもスプリングバックは小さくなる.

\section{参 考 文 献}

1) Takahashi, M.: J. Jpn. Soc. Technol. Plast., 58-673 (2017), 105-109.

2) Karbasian, H. \& Tekkaya, A.E.: J. Mater. Process. Technol., 210-15 (2010), 2103-2118.

3) Yoshida, T.: J. Jpn. Soc. Technol. Plast., 52-606 (2011), 777-781.

4) Yoshida, T., Isogai, E., Hashimoto, K., Katayama, T. \& Kuriyama, Y.: J. Jpn. Soc. Technol. Plast., 46-534 (2005), 656-660.

5) Kojima, N.: J. Jpn. Soc. Technol. Plast., 46-534 (2005), 595-599.

6) Senuma, T., Magome, H., Tanabe, A. \& Takemoto, Y.: J. Jpn. Soc. Technol. Plast., 49-567 (2008), 321-325.

7) Senuma, T., Magome, H., Haga, I., Fujioka, N., Takemoto, Y. \& Shimizu, K.: J. Jpn. Soc. Technol. Plast., 51-594 (2010), 680-684.

8) Yanagimoto, J. \& Oyamada, K.: ISIJ Int., 46-9 (2006), 1324-1328.

9) Wilsius, J., Hein, P. \& Kefferstein, R.: 1. Erlanger Workshop Warmblechumformung 2006, (2006), 83-103.

10) Suehiro, M., Maki, J., Kusumi, K., Ohgami, M. \& Miyakoshi, T.: Nippon Steel Tech. Rep., 378 (2003), 15-21.

11) Japan Sheet Metal Forming Research Group: Press-Seikei-Nani-Handbook 4th Ed., (2017), 221, Nikkan-Kougyo-Shinbunsha.

12) Nakanishi, K. \& Nonomura, F.: R\&D review of Toyota CRDL, 30-4 (1995), 35-45.

13) Uda, K. \& Azushima, A.: J. Jpn. Soc. Technol. Plast., 55-637 (2014), 132-136.

14) Koistinen, D. P. \& Marburger, R. E.: Acta Metall., 7-1 (1959), 59-60.

15) Okamura, K.: Netsu Shori (J. Jpn. Soc. Heat Treat.), 42-5 (2002), 319-325.

16) Japan Sheet Metal Forming Research Group: Press-Seikei-Nani-Handbook 4th Ed., (2017), 319, Nikkan-Kougyo-Shinbunsha. 